論 文

\title{
EPMAによるチタン合金微小領域の 合金元素濃度の定量について
}

德 田祥一*河原弘道**

Shoichi Tokuda and Hiromichi Kawahara : On Quantitative Analysis by EPMA for the Concentration of Alloying Elements in the Micron-Area of Titanium Alloys. As a series of the work to quantitatively make clear the microsegregation in the abnormal microstructure formed in some titanium alloys, the authors tried, at first, to obtain the working curves for $\mathrm{Al}, \mathrm{Fe}, \mathrm{Cr}, \mathrm{Mo}$ and $\mathrm{V}$ in titanium alloys with the purpose of quantitative analysis by EPMA. The accuracy of the analysis by means of the working curves and the possible minimum size of area for micro-area-analysis were also examined. The results are as follows :

(1) Working curves were obtained in the form of a quadratic or linear equation for each alloying element which was less than $20 \mathrm{wt} \%$ in content, using 43 kinds of standard specimens of titanium and titanium alloys. The distribution rate which was obtained from the regression analysis was more than $99 \%$ for each working curve, the error of the working curves being within the range of $0.09 \sim$ $0.38 \mathrm{wt} \%$.

(2) In quantitative analysis of Ti-Fe binary alloys, the measured Fe concentrations of the $\alpha$ and $\beta$ phases were compared with those of the $\alpha$ and $\beta$ phases which were easily assumed from Ti-Fe binary equilibrium diagram, and the results showed good agreement. It was also found that an area of $3 \mu$ square would be sufficient to measure the concentration in the micro-area quantitative analysis.

(3) The quantitative analysis of concentrations in a micro-area, namely the microsegregation analysis of the abnormal microstructures of titanium binary and multiple alloy systems has proved great possibilities by the use of the working curve method with EPMA.

(Received December 16, 1970)

\section{I. 粕言}

EPMA Kよるチタン合金中の微小領域の濃度不均一, すなわち：ミクロ偏析や非金属介在物などの定量について は，報告が注とんどみあたらない，筆者らは，すで報 告(1)したように，チタン合金の熱間圧延板などにあらわれ る異常組織が合金元素の濃縮一ミクロ偏析一に起因してい ることを知った．しかし，定量的にとの偏析を解析するま でには至らなかったそこでこうしたチタン合金中のミク 口偏析を EPMAにより定量的に把握することを試みたが， 実用合金は，一般に 3 元，あるいは 4 元合金であるので検 量線を用いる方法を採用することにし，まずそれを求め た，そして，検量線による定量の精度战よび検出可能な限 界を把握し，EPMAに上る微小領域の定量について検討を したのでここに報告する。

\section{II. 試験材および試験方法}

試験材として, Ti-Fe 2 元系, Ti-Cr 2 元系, Ti-V 2 元 系をそれぞれ 5 種類、Ti-Mo 2 元系，Ti-A1 2 元系をそれ

* 株式会社神戸製鋼所中央研究所 (Central Research Laboratory, Kobe Steel, Ltd., Kobe)

** 株式会社神戸製銅所機械事業部チタン部 (Titanium Department, Machinery Division, Kobe Stee1, Itd., Kobe)
ぞれ 6 種類，実用合金を 5 释類， 3 元牧よび 4 元系の人工 合金を 10 種類，および back ground を知るための高純度 チタン 1 種類を用いた。試料の溶解は, 実用合金の 5 種類 を除きすべて Ar 雾囲気中のタングステン・アークによる ボタン溶解法で行ない, 約 $150 \mathrm{~g}$ のボタン鋳塊を作った. 実用合金は，コンセル・フーク溶解で約 $50 \mathrm{~kg}$ 鋳塊を溶製 した.これらの素材を鍛造で約 $10 \mathrm{~mm} \phi$ に鍜伸した後, 機械加工で $8.5 \mathrm{~mm} \phi \times 10 \mathrm{~mm}$ に仕上げ供試枋とした．各 試料の合金元素含有量は化学分析により正確に分析した が，その結果を用いた合金の種類とともに Table 1 に示し た.

試験方法は次の通りである。まず検量線を求めるための 試料は, 各合金の $\beta$ 相域で均一飞溶体化处理し (Table 1 参照)，約 $0^{\circ} \mathrm{C}$ の水水中に焼入れた。冷却速度は, 計算值 で $4200^{\circ} \mathrm{C} / \mathrm{min}$ である. それらの試料断面のほぼ中央付近 で, 30 100 $\mu$ 間隔で任意江各合金元素毎㵊低 30 点 ${ }^{(2)}$ 測定位置をえらび, $10 \mathrm{sec}$ 間の定時湘定を行ない，それら の計測檤々試料の分析值との関俰を電子計算機 (IBM 360 Model $40 \mathrm{G}$ ) によって処理し, 検量線を

$$
y=a x^{2}+b x+c
$$

（1）德田, 河原, 谷口,津森：金属学会誌，34 (1970)，949. (2) 鈴木 他：金属学会誌, 33(1969), 839. 
Table 1 Chemical composition and heat treatment condition of alloys

\begin{tabular}{|c|c|c|c|c|c|c|}
\hline \multirow{2}{*}{ Alloys } & \multicolumn{5}{|c|}{ Element (wt\%) } & \multirow{2}{*}{ Heat treatment } \\
\hline & $\mathrm{Al}$ & $\mathrm{Cr}$ & $\mathrm{Fe}$ & Mo & $\mathrm{V}$ & \\
\hline $\begin{array}{l}\mathrm{Ti}-1 \mathrm{Fe} \\
\mathrm{Ti}-3 \mathrm{Fe} \\
\mathrm{Ti}-5 \mathrm{Fe} \\
\mathrm{Ti}-8 \mathrm{Fe} \\
\mathrm{Ti}-10 \mathrm{Fe}\end{array}$ & & & $\begin{array}{r}0.90 \\
2.99 \\
5.03 \\
7.69 \\
10.17\end{array}$ & & & $\begin{array}{l}950^{\circ} \mathrm{C} \times 1 \mathrm{hr} \mathrm{W} . \mathrm{Q} . \\
950^{\circ} \mathrm{C} \times 1 \mathrm{hr} \mathrm{W} . \mathrm{Q} . \\
950^{\circ} \mathrm{C} \times 1 \mathrm{hr} \mathrm{W} . \mathrm{Q} . \\
950^{\circ} \mathrm{C} \times 1 \mathrm{hr} \mathrm{W} . \mathrm{Q} . \\
950^{\circ} \mathrm{C} \times 1 \mathrm{hr} \mathrm{W} . \mathrm{Q} .\end{array}$ \\
\hline $\begin{array}{l}\mathrm{Ti}-2 \mathrm{Cr} \\
\mathrm{Ti}-4 \mathrm{Cr} \\
\mathrm{Ti}-11 \mathrm{Cr} \\
\mathrm{Ti}-15 \mathrm{Cr} \\
\mathrm{Ti}-21 \mathrm{Cr}\end{array}$ & & $\begin{array}{r}2.41 \\
4.20 \\
11.04 \\
14.86 \\
21.08\end{array}$ & & & & $\begin{array}{l}950^{\circ} \mathrm{C} \times 1 \mathrm{hr} W . \mathrm{Q} . \\
950^{\circ} \mathrm{C} \times 1 \mathrm{hr} \mathrm{W} . \mathrm{Q} . \\
950^{\circ} \mathrm{C} \times 1 \mathrm{hr} \mathrm{W} . \mathrm{Q} . \\
950^{\circ} \mathrm{C} \times 1 \mathrm{hr} \mathrm{W} . \mathrm{Q} . \\
950^{\circ} \mathrm{C} \times 1 \mathrm{hr} W . \mathrm{Q} .\end{array}$ \\
\hline $\begin{array}{l}\text { Ti-1 Mo } \\
\text { Ti-3 Mo } \\
\text { Ti-6 Mo } \\
\text { Ti-10 Mo } \\
\text { Ti-15 Mo } \\
\text { Ti-20 Mo }\end{array}$ & & & & $\begin{array}{r}1.03 \\
3.04 \\
5.71 \\
9.54 \\
15.43 \\
20.11\end{array}$ & & $\begin{array}{l}950^{\circ} \mathrm{C} \times 1 \mathrm{hr} \mathrm{W} \cdot \mathrm{Q} . \\
950^{\circ} \mathrm{C} \times 1 \mathrm{hr} \mathrm{W} \cdot \mathrm{Q} . \\
950^{\circ} \mathrm{C} \times 1 \mathrm{hr} \mathrm{W} \cdot \mathrm{Q} . \\
950^{\circ} \mathrm{C} \times 1 \mathrm{hr} \mathrm{W} \cdot \mathrm{Q} . \\
950^{\circ} \mathrm{C} \times 1 \mathrm{hr} \mathrm{W} \cdot \mathrm{Q} . \\
950^{\circ} \mathrm{C} \times 1 \mathrm{hr} \mathrm{W} . \mathrm{Q} .\end{array}$ \\
\hline $\begin{array}{l}\text { Ti-1 V } \\
\text { Ti-4 V } \\
\text { Ti-10 V } \\
\text { Ti-16 V } \\
\text { Ti-19 V }\end{array}$ & & & & & $\begin{array}{r}0.85 \\
3.96 \\
9.79 \\
15.97 \\
18.85\end{array}$ & $\begin{array}{l}950^{\circ} \mathrm{C} \times 1 \mathrm{hr} \mathrm{W} \cdot \mathrm{Q} . \\
950^{\circ} \mathrm{C} \times 1 \mathrm{hr} \mathrm{W} \cdot \mathrm{Q} . \\
950^{\circ} \mathrm{C} \times 1 \mathrm{hr} \mathrm{W} . \mathrm{Q} . \\
950^{\circ} \mathrm{C} \times 1 \mathrm{hr} \mathrm{W} . \mathrm{Q} . \\
950^{\circ} \mathrm{C} \times 1 \mathrm{hr} \mathrm{W} . \mathrm{Q} .\end{array}$ \\
\hline High purity $\mathrm{Ti}$ & 一 & - & $<0.009$ & - & - & $700^{\circ} \mathrm{C} \times 1 \mathrm{hr} \mathrm{W} . \mathrm{Q}$ \\
\hline $\begin{array}{l}\text { Ti-5 Al-2 Cr-1 Fe } \\
\text { Ti-8 Al-1 Mo-1 V } \\
\text { Ti-6 Al-4 V } \\
\text { Ti-4 Al-3 Mo-1 V } \\
\text { Ti-16 V-2.5 Al }\end{array}$ & $\begin{array}{l}5.61 \\
8.14 \\
5.71 \\
4.25 \\
2.36\end{array}$ & $\begin{array}{l}2.50 \\
= \\
=\end{array}$ & $\begin{array}{l}0.96 \\
= \\
= \\
-\end{array}$ & $\begin{array}{l}\overline{1.01} \\
\overline{3.04} \\
-\end{array}$ & $\begin{array}{r}\overline{1.03} \\
4.40 \\
1.24 \\
16.08\end{array}$ & $\begin{array}{l}1050^{\circ} \mathrm{C} \times 1 \mathrm{hr} \mathrm{W} . \mathrm{Q} . \\
1150^{\circ} \mathrm{C} \times 1 \mathrm{hr} \mathrm{W} . \mathrm{Q} . \\
1050^{\circ} \mathrm{C} \times 1 \mathrm{hr} \mathrm{W} . \mathrm{Q} . \\
1050^{\circ} \mathrm{C} \times 1 \mathrm{hr} \mathrm{W} . \mathrm{Q} . \\
950^{\circ} \mathrm{C} \times 1 \mathrm{hr} \mathrm{W} . \mathrm{Q} .\end{array}$ \\
\hline $\begin{array}{l}\text { Ti-5 Al-5 Cr-1 Fe } \\
\text { Ti-5 Al-10 Cr-1 Fe } \\
\text { Ti-10 Al-2 Cr-1 Fe } \\
\text { Ti-5 Al-2 Cr-5 Fe } \\
\text { Ti-5 Al-2 Cr-10 Fe }\end{array}$ & $\begin{array}{r}4.91 \\
5.00 \\
10.15 \\
4.97 \\
5.04\end{array}$ & $\begin{array}{l}4.88 \\
9.78 \\
1.94 \\
1.93 \\
1.96\end{array}$ & $\begin{array}{r}1.14 \\
1.14 \\
1.30 \\
5.25 \\
10.23\end{array}$ & & & $\begin{array}{l}1050^{\circ} \mathrm{C} \times 1 \mathrm{hr} \mathrm{W} . \mathrm{Q} . \\
1050^{\circ} \mathrm{C} \times 1 \mathrm{hr} \mathrm{W} \cdot \mathrm{Q} . \\
1100^{\circ} \mathrm{C} \times 1 \mathrm{hr} \mathrm{W} \cdot \mathrm{Q} . \\
1050^{\circ} \mathrm{C} \times 1 \mathrm{hr} \mathrm{W} \cdot \mathrm{Q} . \\
1050^{\circ} \mathrm{C} \times 1 \mathrm{hr} \mathrm{W} . \mathrm{Q} .\end{array}$ \\
\hline $\begin{array}{l}\text { Ti-4 Al-7 Mo-1 V } \\
\text { Ti-4 Al-10 Mo-1 V } \\
\text { Ti-8 Al-4 Mo-1 V } \\
\text { Ti-8 Al-8 Mo-1 V } \\
\text { Ti-6 Al-10 V }\end{array}$ & $\begin{array}{l}4.23 \\
4.12 \\
8.17 \\
8.12 \\
6.13\end{array}$ & & & $\begin{array}{r}7.63 \\
10.29 \\
4.14 \\
8.41 \\
-\end{array}$ & $\begin{array}{l}0.98 \\
1.01 \\
1.01 \\
0.93 \\
9.50\end{array}$ & $\begin{array}{l}1100^{\circ} \mathrm{C} \times 1 \mathrm{hr} \mathrm{W} \cdot \mathrm{Q} . \\
1100^{\circ} \mathrm{C} \times 1 \mathrm{hr} \mathrm{W} \cdot \mathrm{Q} . \\
1100^{\circ} \mathrm{C} \times 1 \mathrm{hr} \mathrm{W} \cdot \mathrm{Q} . \\
1100^{\circ} \mathrm{C} \times 1 \mathrm{hr} \mathrm{W} \cdot \mathrm{Q} . \\
1100^{\circ} \mathrm{C} \times 1 \mathrm{hr} \mathrm{W} \cdot \mathrm{Q} .\end{array}$ \\
\hline $\begin{array}{l}\text { Ti-1 A1 } \\
\text { Ti-5 A1 } \\
\text { Ti-8 A1 } \\
\text { Ti-11 A1 } \\
\text { Ti-16 A1 } \\
\text { Ti-22 A1 }\end{array}$ & $\begin{array}{r}1.25 \\
4.91 \\
7.99 \\
11.24 \\
16.35 \\
21.99\end{array}$ & & & & & $\begin{array}{l}1050^{\circ} \mathrm{C} \times 1 \mathrm{hr} \mathrm{W} \cdot \mathrm{Q} . \\
1150^{\circ} \mathrm{C} \times 1 \mathrm{hr} \mathrm{W} \cdot \mathrm{Q} . \\
1200^{\circ} \mathrm{C} \times 1 \mathrm{hr} \mathrm{W.Q} . \\
1200^{\circ} \mathrm{C} \times 1 \mathrm{hr} \mathrm{W} . \mathrm{Q} . \\
1250^{\circ} \mathrm{C} \times 1 \mathrm{hr} \mathrm{W} . \mathrm{Q} . \\
1300^{\circ} \mathrm{C} \times 1 \mathrm{hr} \mathrm{W} . \mathrm{Q} .\end{array}$ \\
\hline
\end{tabular}

度で保持し，その $\alpha$ 相, $\beta$ 相の平衡状 態図で示される $\mathrm{Fe}$ 濃度を検出しろる かどうかを試験した。.すなわち，Ti$1 \mathrm{Fe}(\mathrm{Fe}: 1.03 \mathrm{wt} \%)$, Ti-3 Fe (Fe:3.17 wt \%) 2 元系合金を $950^{\circ} \mathrm{C} \times 1 \mathrm{hr}$, 溶 体化処理し, $830^{\circ}, 750^{\circ}, 650^{\circ} \mathrm{C}$ の各 温度に焼入れ，5時間保持後， $0^{\circ} \mathrm{C}$ の 氷水中に焼入れた試験片について, $\alpha$ 相と $\beta$ 相中の $\mathrm{Fe}$ 濃度を定量し，平衡 状態図から得られる $\mathrm{Fe}$ 濃度と比較し た. 測定法は, $10 \mathrm{sec}$ の定時点分析法 をとり，一試片について最低 30 点を 測定した. 测定点はあらかじめ光学顕 微鏡写真をとって $\alpha$ 相, $\beta$ 相を区別し て決めて执き，実際の測定にあたって はそれと対比しながら行なった. 測定 の前には, 三つ以上の標準試料(検量 線を求めたときの試料)で $\mathrm{X}$ 線強度を 必ず測定して検量線を確認するように した.

EPMA 装置は，島津製 ARL-EMX 2 型で, 設定は加速電圧が $20 \mathrm{keV}$, 結 晶は $\mathrm{LiF}(\mathrm{Fe}, \mathrm{Cr}, \mathrm{V}$ に対して), $\mathrm{ADP}$ (Moに対して)，特よび $\mathrm{KAP}(\mathrm{Al}$ に対 して), 電子線径は約 $1 \mu$, 特性X線 は, $\mathrm{K} \alpha(\mathrm{Fe}, \mathrm{Cr}, \mathrm{V}, \mathrm{Al})$ および $\mathrm{L} \alpha(\mathrm{Mo})$ を用いた，測定試片の調整は，樹脂に マウントし，測定面をアルミナでバフ 研摩し, そのあと硝弗酸で軽くエッチ した.

\section{III. 試 験 結 果}

\section{1. 検 吾 線}

検量線用試料によって測定した結果 を電子計算機で処理し, 回帰式として 検量線を数式で求めたが，それらを回

の 2 次式で近似した。 ここで, $y$ は計測值 (count/10 sec), $x$ は合金元素含有量 $(\mathrm{wt} \%), a, b$ および $c$ は回帰係数およ び定数である. 検量線を式で示すにあたっては, 回帰係数 の $\mathrm{F}$ 検定を行ない，5\% 有意水準で有意であることを確か め, それらの係数と計測值のバラッキや相関係数, 寄与率 あ求めた. な拉， 2 元系と多元系とでは, 電子線や特性 $\mathrm{X}$ 線の吸収などの効果が当然異なるので, 同一元素に対する 検量線をそれぞれについて求めた。

次にこれらの検量線を使って，2相合金に扣ける各相に ついでの程度の微小領域まで定量が行なえるかを確認す るために, Ti-Fe 2 元系合金を $\beta$ 溶体化処理後, $\alpha+\beta$ 相温
帰分析結果とともに Table 2 に示す. 縦軸に計測值, 横 軸に各元素の含有量(化学分析值)をとって, グラフ化して 示したものが Fig.1～Fig.5 であり， 2 元系と多元系とを 区別して記した. また, 多元系では, 対象とする元素の計 測值の平均值もプロットした.

Cr と V の検量線は，2 元系と多元系で差が䜑められず, 同一の検量線で定量できるが，とくにVは非常によい一致 をし，2次式としてあらわすことができた，Fe，Mo，Al は, 2 元系之多元系で検量線が異なり，2 元系では 2 次 式で，多元系では 1 次式であらわすことができた。 $\sigma_{y}$ と $\sigma_{(y m-\hat{y})}$ とを比較することによって，両者が各元素ともほ 
Table 2 Result of regression analysis and equations of working curve for each elements

\begin{tabular}{|c|c|c|c|c|c|c|c|c|}
\hline Element & Alloy system & Equation of working curve & $\sigma_{a}$ & $\sigma_{b}$ & $\sigma_{y}$ & $r(\%)$ & D.R. $(\%)$ & $\sigma_{(y m-\hat{y})}$ \\
\hline $\mathrm{Fe}$ & $\begin{array}{l}\text { binary } \\
\text { multiple }\end{array}$ & $\begin{array}{l}y=-92.10 x^{2}+5562 x+742 \\
y= \\
4268 x+910\end{array}$ & 2.3 & $\begin{array}{r}22.7 \\
7.9\end{array}$ & $\begin{array}{l}454 \\
388\end{array}$ & $\begin{array}{l}99.96 \\
99.96\end{array}$ & $\begin{array}{l}99.92 \\
99.93\end{array}$ & $\begin{array}{l}450 \\
387\end{array}$ \\
\hline $\mathrm{Cr}$ & $\begin{array}{l}\text { binary and } \\
\text { multiple }\end{array}$ & $y=-10.56 x^{2}+2303 x+280$ & 0.38 & 7.5 & 287 & 99.98 & 99.95 & 285 \\
\hline Mo & $\begin{array}{l}\text { binary } \\
\text { multiple }\end{array}$ & $\begin{array}{l}y=-6.35 x^{2}+1914 x+642 \\
y= \\
1574 x+725\end{array}$ & $\frac{0.58}{-}$ & $\begin{array}{r}11.4 \\
9.1\end{array}$ & $\begin{array}{l}377 \\
477\end{array}$ & $\begin{array}{l}99.95 \\
99.65\end{array}$ & $\begin{array}{l}99.91 \\
99.31\end{array}$ & $\begin{array}{l}374 \\
477\end{array}$ \\
\hline $\mathrm{V}$ & $\begin{array}{l}\text { binary and } \\
\text { multiple }\end{array}$ & $y=-14.63 x^{2}+2216 x+1155$ & 0.33 & 6.0 & 187 & 99.99 & 99.98 & 194 \\
\hline $\mathrm{Al}$ & $\begin{array}{l}\text { binary } \\
\text { multiple }\end{array}$ & $\begin{array}{l}y=-6.99 x^{2}+2458 x+1152 \\
y=\quad 2625 x+925\end{array}$ & 1.29 & $\begin{array}{r}28.8 \\
6.4\end{array}$ & $\begin{array}{l}896 \\
309\end{array}$ & $\begin{array}{l}99.87 \\
99.91\end{array}$ & $\begin{array}{l}99.73 \\
99.82\end{array}$ & $\begin{array}{l}892 \\
305\end{array}$ \\
\hline
\end{tabular}

$y$ : Counting rate (Counts per $10 \mathrm{sec}$ )

$x$ : Content (wt $\%$ )

$\sigma_{a}$ : Standard error of coefficient for $x^{2}$

$\sigma_{b}:$ Standard error of coefficient for $x$

$\sigma_{y}:$ Standard error of $y$

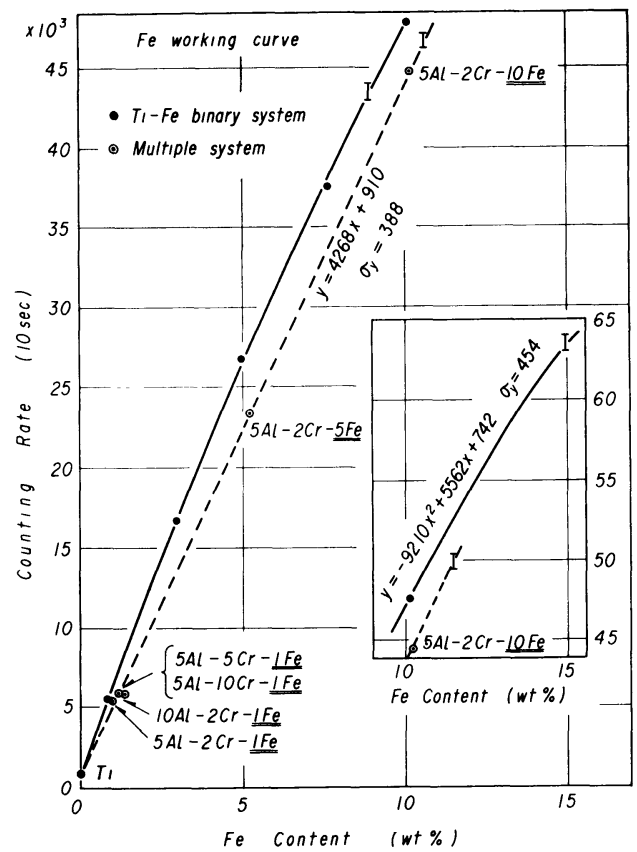

Fig.1 Working curves of $\mathrm{Fe}$ in titanium binary and multiple system

洼完全に等しく，検量線を示す式が正しいことがわかる. また，寄与率(D.R.)は，すべて $99 \%$ 以上であり，一般に は95\% 以上であればかなりの正確さがあると判断してよ いので, ここに得た検量線の信頼度はかなり高いものと考 えることがでさる. 相関係数 $(\gamma)$ も参考までに併記したが, 測定値の推定值からのバラッキをあらわしていると考えて よい.

求めた検量線の誤差は, 試料の化学分析の誤差も含んだ 計測值の標準誤差 $\sigma_{y}$ から知ることができる．各合金元素 含有量の範用は 1 20 wt \% であり， $5 \mathrm{wt} \%$ 前後の含有量 で誤差を考えると Table 3 に示すと扣りである。補正計 $\gamma:$ Multiple correlation coefficient $(\%)$

D.R. : Distribution rate (\%)

$y_{m}$ : Measured counting rate (C.P.10 sec)

$\hat{y}$ : Assumed counting rate (C.P.10 sec)

$\sigma_{(y m-\hat{y})}:$ Standard error of $\left(y_{m}-\hat{y}\right)$

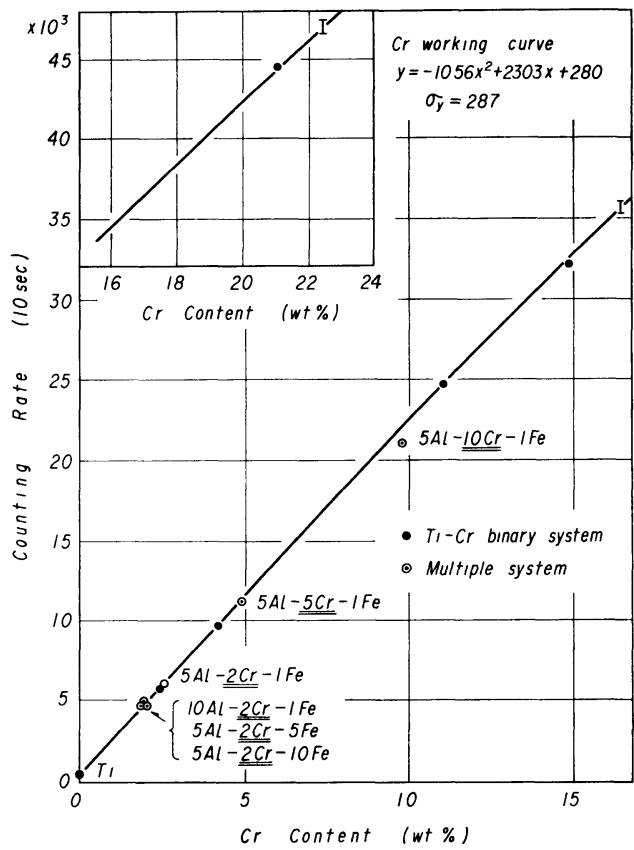

Fig.2 Working curve of $\mathrm{Cr}$ in titanium binary and multiple system

算で定量する方法の場合は，かなり条件のよいときでる

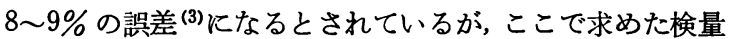
線の誤差はそれよりあずっと小さく，かなり精度のよいこ とを示している.

\section{2. 定是分析試験}

2 相合金の各相の微小領域の合金元素濃度が精度よく検 出にかかるかどうかを確かめるためのものである.すでに のベた熱処理をした Ti-1 Fe, Ti-3 Fe 合金の光学顕微鏡組 織を Photo.1， 2 に示す. $10 \mathrm{sec}$ 間の点分析結果を検量線

( 3 ) N.Swindells : J.Inst.Metals, 95 (1967), 316. 


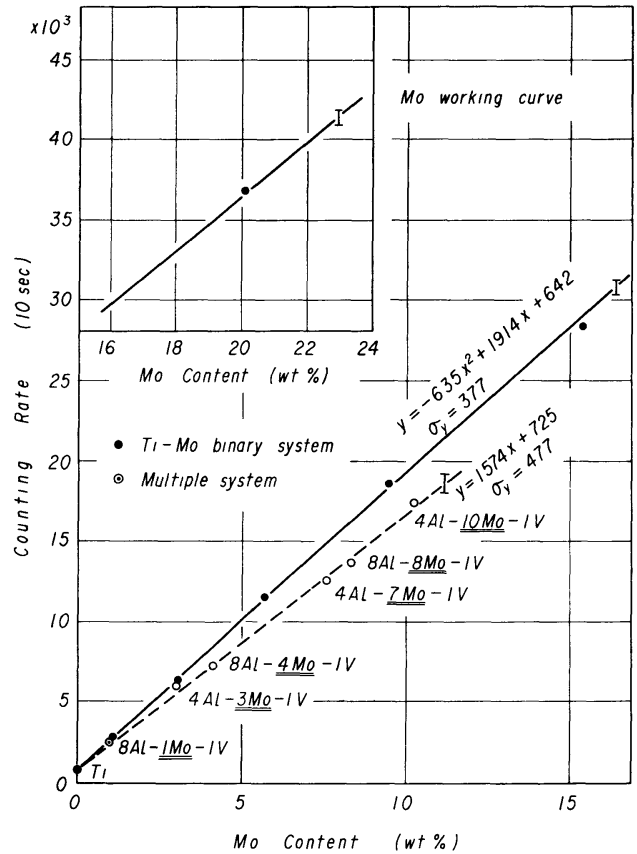

Fig.3 Working curves of Mo in titanium binary and multiple system

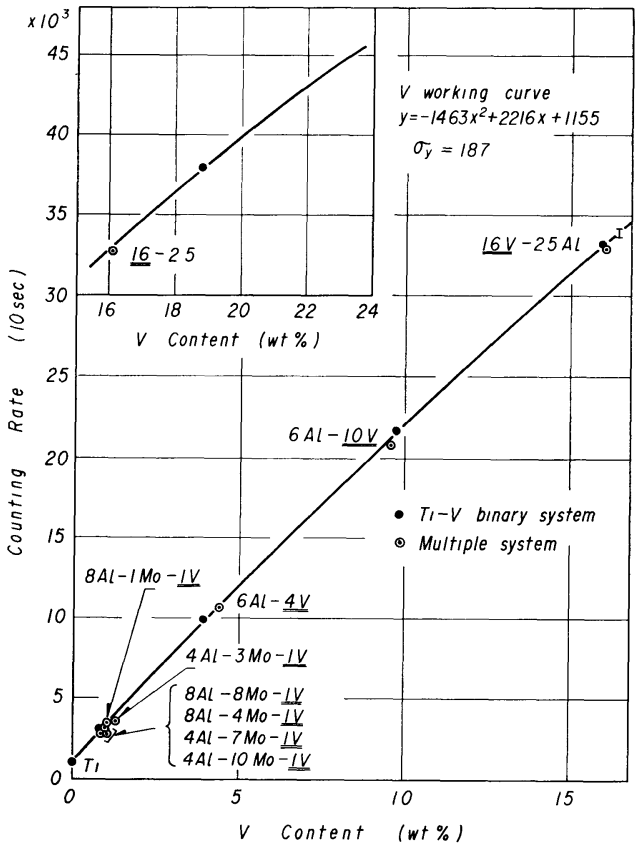

Fig.4 Working curve of $\mathrm{V}$ in titanium binary and multiple system

を用いて Fe 濃度定量值になお し, その最大, 最小濃度を $\mathrm{Ti}-\mathrm{Fe} 2$ 元系平衡状態図 ${ }^{(4)}$ 上に書き入れたものが Fig.6で ある. 各試料について得られた $\mathrm{Fe}$ 濃度に対する測定数の 分布を Fig.7に示す. $830^{\circ} \mathrm{C}$ で恒温変態処理をした試料で

(4) M.Hansen : Constitution of Binary Alloys, McGrawHill Book Company Inc., (1958), 723.

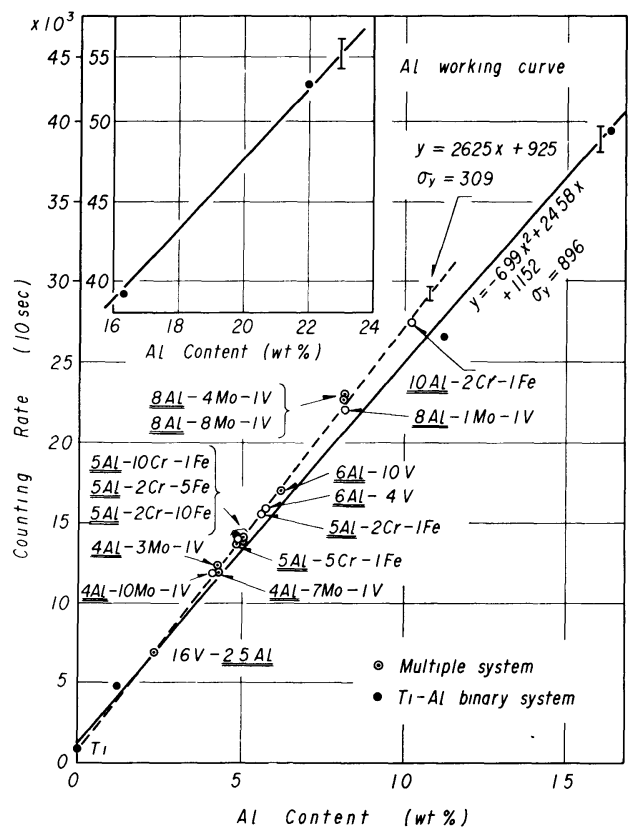

Fig.5 Working curves of $\mathrm{Al}$ in titanium binary and multiple system

Table 3 Accuracy of working curves obtained

\begin{tabular}{c|l|c|c}
\hline \hline Element & Alloy system & $\begin{array}{l}\text { Quantitative } \\
\text { error obtaind } \\
\text { from } \sigma_{\boldsymbol{y}}(\mathrm{wt} \%)\end{array}$ & $\begin{array}{c}\text { Mean error of } \\
\text { working curve } \\
\text { at about 5 wt\% }\end{array}$ \\
\hline $\mathrm{Fe}$ & $\begin{array}{l}\text { binary } \\
\text { multiple }\end{array}$ & $\begin{array}{l}0.15 \\
0.09\end{array}$ & $\begin{array}{l}\text { abt. } 3.0 \\
\text { abt. 1.8 }\end{array}$ \\
\hline $\mathrm{Cr}$ & $\begin{array}{l}\text { binary and } \\
\text { multiple }\end{array}$ & 0.13 & abt. 2.6 \\
$\mathrm{Mo}$ & $\begin{array}{l}\text { binary } \\
\text { multiple }\end{array}$ & 0.20 & abt. 4.0 \\
$\mathrm{~V}$ & $\begin{array}{l}\text { binary and } \\
\text { multiple }\end{array}$ & 0.30 & abt. 6.0 \\
\hline $\mathrm{Al}$ & binary & 0.38 & abt. 1.8 \\
\hline
\end{tabular}

は, Photo.1, 2 の組織，および Fig.7 の測定值の分布から わかるように， $\alpha$ 相と $\beta$ 相とを十分区別して測定でき，そ れらの Fe 濃度は状態図の濃度とかなりよい一致を示し た. また, $750^{\circ} \mathrm{C}$ の試料では, $\alpha$ 相と $\beta$ 相が一見区別しに くいよ5に見え, Fig.7 からも測定值の分布は, 低濃度と 高濃度側に分離はしないが, 状態図の Fe 濃度とかなり一 致をし， $\beta$ 相濃度の定量ができることを示している．しか し, $650^{\circ} \mathrm{C}$ の試料では, $\beta$ 相の $\mathrm{Fe}$ 濃度は状態図のそれと 一致せず，ずっと低い值しか得られなかった。これは $\beta$ 相 量が非常に少なく, したがって, $\beta$ 相の面積が小さいため 隣接する $\alpha$ 相にも電子線があたり, 結果として $\beta$ 相と $\alpha$ 相 の平均した $\mathrm{Fe}$ 濃度を測定することになったためと， 650 


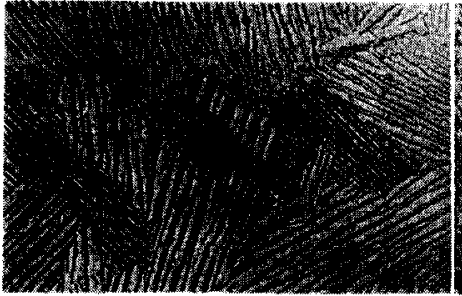

$(\times 200 \times 1 / 2)$

Fe concentration $\alpha$ phase : $0.04 \mathrm{wt} \%$ $\beta$ phase : $2.7 \mathrm{wt} \%$ $950^{\circ} \mathrm{C} \times 1 \mathrm{hr} \rightarrow 830^{\circ} \mathrm{C} \times 5 \mathrm{hr}$ W.Q. $\mathrm{HF}+\mathrm{HNO}_{3}$ etching Photo.1

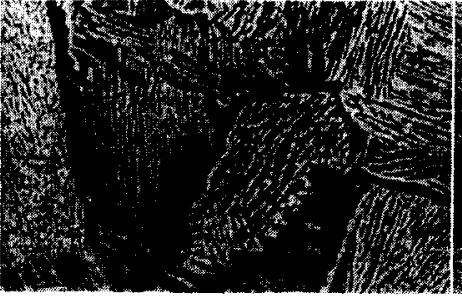

Fe concentration $\alpha$ phase $: 0.05 \mathrm{wt} \%$ $\beta$ phase : $8.9 \mathrm{wt} \%$ $950^{\circ} \mathrm{C} \times 1 \mathrm{hr} \rightarrow 750^{\circ} \mathrm{C} \times 5 \mathrm{hr}$ W.Q. $\mathrm{HF}+(\mathrm{COOH})_{2}$ etching

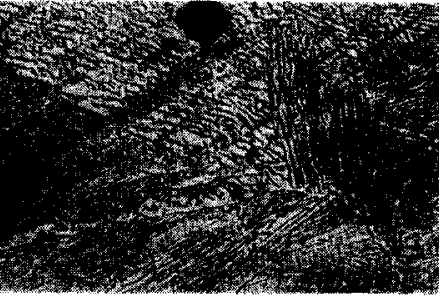

$(\times 200 \times 1 / 2)$

Fe concentration $\alpha$ phase $: 0.04 \mathrm{wt} \%$ $\beta$ phase : $2.5 \mathrm{wt} \%$

$950^{\circ} \mathrm{C} \times 1 \mathrm{hr} \rightarrow 650^{\circ} \mathrm{C} \times 5 \mathrm{hr}$ W.Q. $\mathrm{HF}+\mathrm{HNO}_{3}$ etching

Optical microstructure of Ti-1 $\mathrm{Fe}$ binary alloy

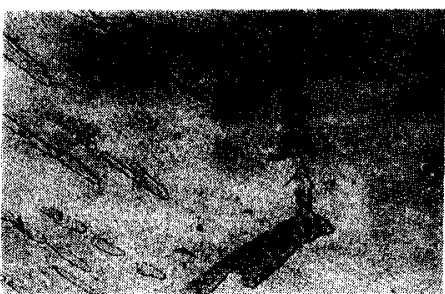

$(\times 200 \times 1 / 2)$

Fe concentration

$\alpha$ phase $: 0.06 \mathrm{wt} \%$ $\beta$ phase : $3.3 \mathrm{wt} \%$

$950^{\circ} \mathrm{C} \times 1 \mathrm{hr} \rightarrow 830^{\circ} \mathrm{C} \times 5 \mathrm{hr}$ W.Q. $\mathrm{HF}+\mathrm{HNO}_{3}$ etching

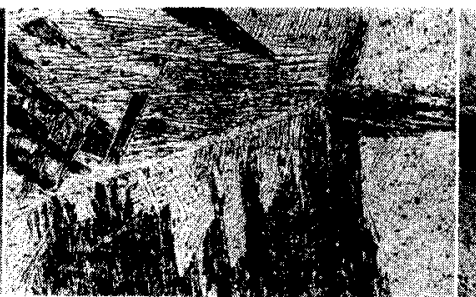

$(\times 200 \times 1 / 2)$

Fe concentration $\alpha$ phase : $0.2 \mathrm{wt} \%$ $\beta$ phase : $7.2 \mathrm{wt} \%$

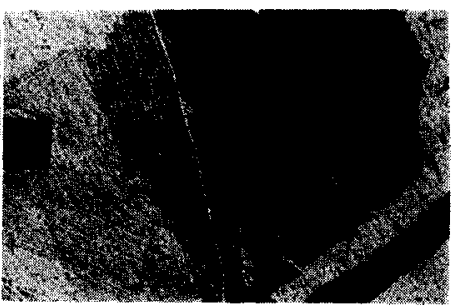

$(\times 200 \times 1 / 2)$

Fe concentration $\alpha$ phase : $0.4 \mathrm{wt} \%$ $\beta$ phase : $3.6 \mathrm{wt} \%$ $950^{\circ} \mathrm{C} \times 1 \mathrm{hr} \rightarrow 750^{\circ} \mathrm{C} \times 5 \mathrm{hr}$ W.Q. $\quad 950^{\circ} \mathrm{C} \times 1 \mathrm{hr} \rightarrow 650^{\circ} \mathrm{C} \times 5 \mathrm{hr} \mathrm{W.Q}$. $\mathrm{HF}+\mathrm{HNO}_{3}$ etching $\mathrm{HF}+\mathrm{HNO}_{3}$ etching Photo. 2 Optical microstructure of Ti-3 Fe binary alloy

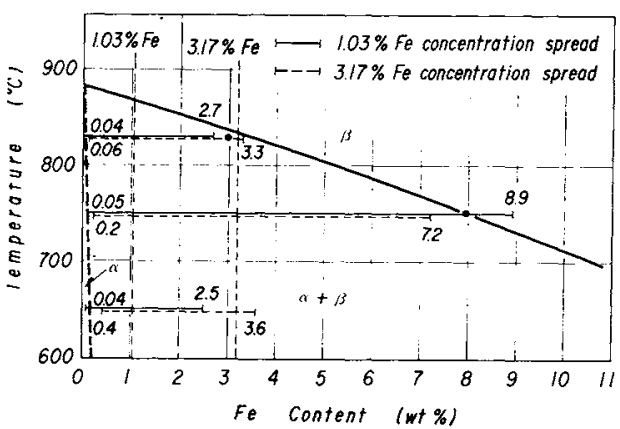

Fig.6 Concentration spread of $\mathrm{Fe}$ in $\mathrm{Ti}-1 \mathrm{Fe}$ and $\mathrm{Ti}-3 \mathrm{Fe}$ isothermal treated

${ }^{\circ} \mathrm{C} \times 5 \mathrm{hr}$ の熱処理では未だ平衡状態に達していないと考 えられこれら二つの原因によるものと思秃るる。しかし いずれにしても，求めた検量線を使った Fe 濃度の定量は， Photo.1，2 からかかるよ5に， $3 \mu$ 平方程度の面積が势れ ば $\left(750^{\circ} \mathrm{C}\right.$ 恒温変態の組織) 十分可能であり，Fe 以外の元 素についても，いわゆる微小領域の濃度定量がかなりよい 精度で行なえることを示していると考觉てょかるう。

\section{IV. 考察}

得られた検量線で特長的なことは，2元系がすべて 2 次 曲線で示され，多元系のうち $\mathrm{Fe}, \mathrm{Mo}, \mathrm{Al}$ が直線であるこ と，敊上び $\mathrm{Al}$ の場合の及が多元系が 2 元系上りす等しい
$\mathrm{Al}$ 含有量に対してX線強度が高いことである。

2 元系では，X線に対する種々の要因の影響，たとえば 吸取や螢光励起作用があるため, 検量線は 1 次ではなく， 当然 2 次曲線になる可能性が強いと考它られる，多元系に おける Fe, Mo, Al の検量線の直線性について考えてみる と，対象とする元素の特性X線の発生挙動は，2 元系であ れ，多元系であれ全く同様であり，第 3 あるいは第 4 元素 の含有量が一定であれば 2 元系と同じく2 次曲線になるは ずである．しかしここでは，第 3 あるいは第 4 元素の含有 量が变化しているため，2 元系汇和计る傾向はそのまます 古来たされないと考兄られる，とはいうるのの，直線性を 与えることにはならず，不規則性が子想されるが，統計解 析による $95 \%$ 信頼限界では直線仿よる近似が，この実験 の籁囲内では最す精度がよいという実駼結果を示している もの之解釈できる。 また Mo, Al の場合の多元系では，2 元系の場合よりる対象とする元素の含有量が低く，10 wt\% 程度をでであったため，ゆるやかな曲線部分の一部として 直線性が生玉れたことも考えられるが，いずれにしても， 第 3 招よび第 4 元素の影響が入りくんで，統計的あるいは 実験的にみて直線性が得られたと考㝋た力がよさそうであ る。

次に 2 元系に拈ける检量線の 2 次項の符号について考兄 てみよう，それには，各元素の質量吸収係数(5)，螢光励起 効果の程度を示す Excitation efficiency ${ }^{(6)}$ 抽よび原子番号 


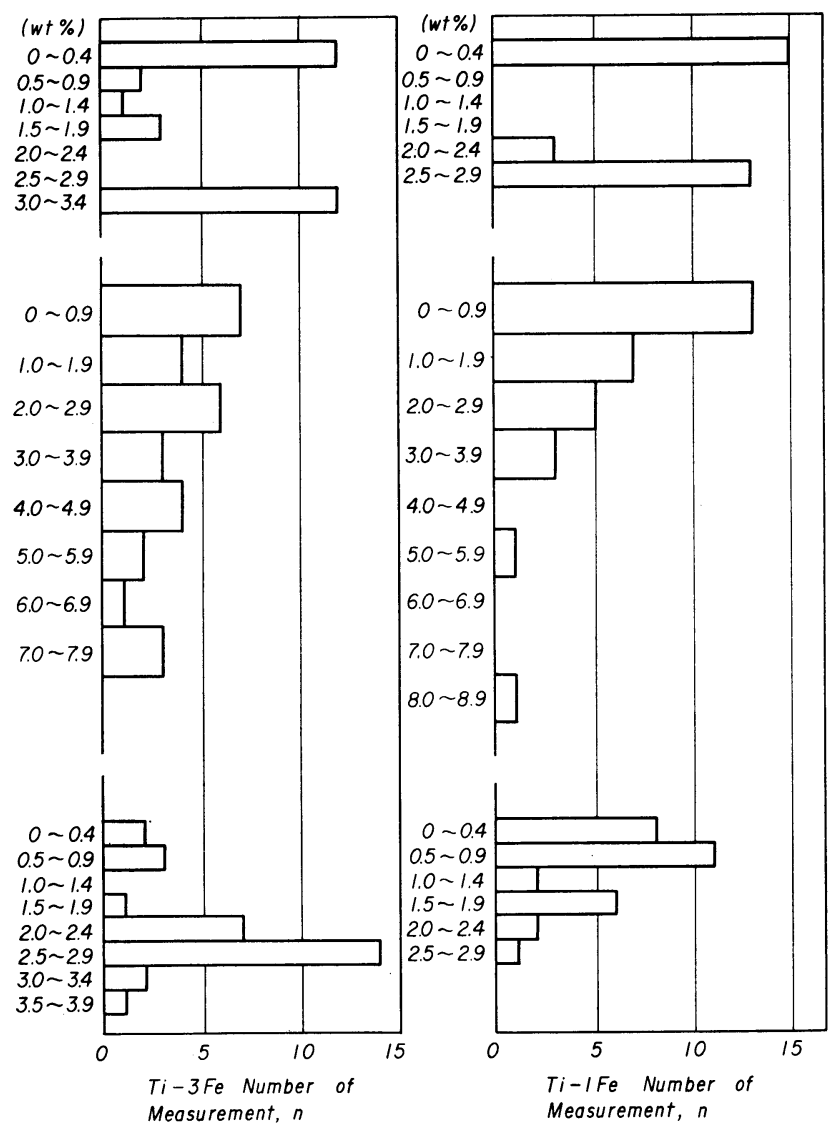

Fig.7 Distribution of measurement frequency in Fe concentration for $\mathrm{Ti}-1 \mathrm{Fe}$ and $\mathrm{Ti}-3 \mathrm{Fe}$ isothermal treated

Table 4 Mass absorption coefficient of Al, $\mathrm{Cr}, \mathrm{V}, \mathrm{Fe}$ and $\mathrm{Mo}$

\begin{tabular}{l|r|r|r|r|r|r}
\hline \hline \multirow{2}{*}{ X-ray } & \multicolumn{6}{|c}{ Absorber } \\
\cline { 2 - 7 } & $\mathrm{Al}$ & $\mathrm{Ti}$ & $\mathrm{V}$ & $\mathrm{Cr}$ & $\mathrm{Fe}$ & Mo \\
\hline $\mathrm{Al} \mathrm{K} \alpha$ & 300 & 2200 & 2480 & 2700 & 3200 & 2250 \\
$\mathrm{~V} \mathrm{~K} \alpha$ & 190 & 80 & 125 & 135 & 160 & 515 \\
$\mathrm{Cr} \mathrm{K} \alpha$ & 150 & 510 & 100 & 107 & 125 & 410 \\
$\mathrm{Fe} \mathrm{K} \alpha$ & 92 & 330 & 410 & 460 & 76 & 270 \\
$\mathrm{Mo} \mathrm{L} \alpha$ & 1620 & 710 & 860 & 940 & 1160 & 720 \\
\hline
\end{tabular}

効果の係数 (7)を考えねばならず，それらを Table 4, 5, 6 に示す.

Ti-Mo 系と Ti-Al 系では, 螢光励起効果があ り, 質量吸収係数の含有量増加にともなう大小関 係，拉よび特に $\mathrm{A} 1$ の場合は原子番号効果を考 えても検量線の 2 次項の係数はマイナスになる ことが容易に考えられる．すなわち，Moでは $(\mu / \rho){ }_{\mathrm{MoL} \alpha}^{\text {Alloy }}$ は含有量増加にともなってほとんど大 きくならず，原子番号効果はわずかに影響するが 無視しうる程度で, 螢光励起の影響が最もよくき き， X線強度が増す， $\mathrm{Al}$ では，螢光励起効果は あるが，概算すると原子番号効果でほとんど相殺 され， $(\mu / \rho){ }_{\text {Alk } \alpha}^{\text {Alloy }}$ は含有量増加とともに小さくな り，X線強度が増す。つまり係数はマイナスにな るのである. Ti-Fe系と Ti-Cr系では螢光励起 はなく，原子番号効果すわずかで考える必要は ないとすると，質量吸収係数の影響だけを考え ればよい. 含有量增加にともなって $(\mu / \rho)_{\text {Crha， }}^{\text {Alloy }}$ $(\mu / \rho)_{\mathrm{FeK} \boldsymbol{\alpha}}^{\mathrm{Alloy}}$ は小さくなるので，X線強度は大とな り係数はマイナスになることがわかる。一方， Ti-V 系では螢光励起はなく，原子番号効果を無 視しうるのは Ti-Cr 系, Ti-Fe 系之同様であるが 質量吸収係数の影響は逆で，含有量増加とともに $(\mu / \rho) \underset{\mathrm{VK} \boldsymbol{\alpha}}{\mathrm{Alloy}}$ は大きくなり，したがって 2 次項の係 数はプラスになることが考えられ，得られた結果 と一致しない. Ti-Al-V 3 元系で, Ti-6 Al-4 V, Ti-6 Al-10 V の実測值, および Ti-2.5 Al-16 V を Ti-6 Al-16 V に換算した $(\mu / \rho)_{\mathrm{VK} \boldsymbol{\alpha}}^{\mathrm{Alloy}}$ の増加分 Table 6 Multiplier for atomic number correction

\begin{tabular}{c|c|c}
\hline Atom & $Z$ & Multiplier, $P_{\boldsymbol{Z}}$ \\
\hline $\mathrm{Al}$ & 13 & 1.11 \\
$\mathrm{Ti}$ & 22 & 1.02 \\
$\mathrm{~V}$ & 23 & 1.02 \\
$\mathrm{Cr}$ & 24 & 1.01 \\
$\mathrm{Fe}$ & 26 & 1.00 \\
$\mathrm{Mo}$ & 42 & 0.96 \\
\hline
\end{tabular}

Table 5 Excitation efficiency for $\mathrm{Al}, \mathrm{Ti}, \mathrm{V}, \mathrm{Cr}, \mathrm{Fe}$ and $\mathrm{Mo}$

\begin{tabular}{|c|c|c|c|c|c|c|c|}
\hline \multirow{3}{*}{$\begin{array}{l}\text { Element being } \\
\text { excited }\end{array}$} & \multirow{3}{*}{$\begin{array}{l}\text { Absorption } \\
\text { edge } \lambda(\AA)\end{array}$} & \multicolumn{6}{|c|}{ Excitation efficiency, $E z_{\lambda}{ }^{*}(\%)$} \\
\hline & & \multicolumn{6}{|c|}{ Exciting X-rays } \\
\hline & & $\begin{array}{l}\mathrm{A} 1 \mathrm{~K} \alpha \\
\lambda=8.3 \AA\end{array}$ & $\begin{array}{c}\mathrm{Ti} \mathrm{K} \alpha \\
\lambda=2.74 \AA\end{array}$ & $\begin{array}{r}\mathrm{V} \mathrm{K} \alpha \\
\lambda=2.50 \AA\end{array}$ & $\begin{array}{c}\mathrm{Cr} \mathrm{K} \alpha \\
\lambda=2.29 \AA\end{array}$ & $\underset{\lambda=1.93 \AA}{F e ~ K \alpha}$ & $\begin{array}{l}\text { Mo L } \alpha \\
\lambda=5.4 \AA\end{array}$ \\
\hline $\begin{array}{l}\mathrm{Al} \\
\mathrm{Ti} \\
\mathrm{V} \\
\mathrm{Cr} \\
\mathrm{Fe} \\
\mathrm{Mo}\end{array}$ & $\begin{array}{l}7.96 \\
2.49 \\
2.26 \\
2.07 \\
1.74 \\
4.31\end{array}$ & $\begin{array}{l}- \\
- \\
- \\
-\end{array}$ & $\begin{array}{c}0.33 \\
\overline{-} \\
\overline{-} \\
4.8\end{array}$ & $\begin{array}{c}0.25 \\
- \\
\overline{-} \\
4.0\end{array}$ & $\begin{array}{c}0.1 \\
13.8 \\
- \\
- \\
- \\
3.4\end{array}$ & $\begin{array}{r}0.1 \\
12.0 \\
14 ? \\
16.3 \\
\overline{2.3}\end{array}$ & $\begin{array}{c}0.45 \\
- \\
- \\
-\end{array}$ \\
\hline
\end{tabular}

* $E z_{\lambda}, Z$ : Element being excited $\lambda$ : Wave length of exciting X-ray

(5) L.S.Birks : Electron Probe Microanalysis, Interscienc Publishers, (1963), 201.
(6) L. S. Birks : Electron Probe Microanalysis, Interscience Publishers, (1963), 177. 
を考只 Fig. 4 上で比較しても，やはり 2 次項の係数はマイ

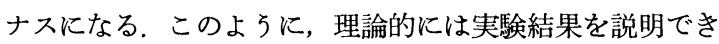
ないが, Table 4 の質量吸収係数の誤差は $5 \%$ より小さく はない(5)とされていること，括よび測定值の統計解析で 95\% 信頼限界をとっていることからそうした誤差を含ん でいるためと思われる。 こうしたことは，他の系でも当然 いえることである.

2 元系と多元系で同一元素, 同一含有量でX線強度が異 なる点について検討してみよう，各系について，質量吸収 係数の影響, 螢光励起効果, 原子番号効果の大きさをそれ ぞれ概算して比較すると，まずMoを含むTi-Al-Mo-V系 の場合， $(\mu / \rho){ }_{\mathrm{MoL} \alpha}^{\mathrm{Al}}$ は，かなり大きく，( $(\mu / \rho)_{\mathrm{MoL} \alpha}^{\mathrm{Ti}}$ が一番

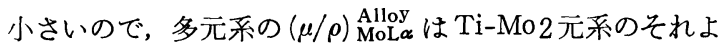
り $5 \%$ 以上大きくなり，一方，Moは $\mathrm{TiK} \alpha$ とK $\alpha$ によ って溃光励起されるが, TiK $\alpha$ に上る螢光励起がよくきき, 2 元系の方がその効果が大きい. 原子番号効果は無視し5 る程度である. したがって, Ti-Mo 2 元系のX線強度は多 元系上りも大となり，得られた結果と傾向は一致する.

$\mathrm{Cr}$ を含む $\mathrm{Ti}-\mathrm{Al}-\mathrm{Cr}-\mathrm{Fe}$ 系の場合, $(\mu / \rho)_{\mathrm{CrK} \boldsymbol{\alpha}}^{\mathrm{Ti}}$ が一番大 きいので， $\mathrm{Al}$ 扣よび $\mathrm{Fe}$ が加わることによって，多元系の $(\mu / \rho)_{\text {CrKa }}^{\text {Alloy }}$ は 2 元系のそれより $4 \%$ 程度は小さくなり, 原 子番号効果は無視できるとしても，その上に $\mathrm{Cr}$ は F F K $\alpha て ゙$ 螢光励起されるので, 理論的には多元系のX線強度は TiCr 2 元系上り強くなる. しかし実際には, 両者侍が認め られないという結果になっている.

Vを含むTi-Al-V- (Mo) 系では, 螢光励起はなく, 原子 番号効果も無視しうる程度であり, 吸収効果の久を考学る と, $(\mu / \rho)_{\mathrm{VK} \alpha}^{\mathrm{Ti}}$ が一番小さく，したがって，多元系の $(\mu / \rho)_{\mathrm{VK} \alpha}^{\text {Alloy }}$ は Al 含有量に左右されるが, Ti-V 2 元系のそ れより理論的には3〜7\%，あるいはそれ以上大きくなる. すなわち，それだけ多元系のX線強度は低くなるはずであ るが，結果では両者に差が認められない。

$\mathrm{Al}$ を含む多元系では, 吸収効果, 螢光励起効果, 原子 番号効果をすべて考える必要がある。吸收効果の影響は小 さく，多元系の $(\mu / \rho)_{\mathrm{AlK} \boldsymbol{\alpha}}^{\mathrm{Allog}}$ は，Ti-A1 2 元系のそれよりわ ずかに $(1 \%$ 以下 $)$ 大きく，原子番号効果も多元系の $X$ 線強 度を低くする方向にわずかではあるが働く，一方，螢光励 起は, Ti, V, Cr, Fe の K $\alpha$, MoL $\alpha$ Kょって受けるが, $\mathrm{MoL} \alpha$ と VK $\alpha$ の影響が大きいので ( $3 \%$ 以下の増加), $\mathrm{M}^{\mathrm{o}}$ とVを含む多元系では総合的に Ti-Al 2 元系より X 線強度 が大きくなる傾向であり，Cr と Fe を含む多元系では，螢

(7) L.S. Birks : Electron Probe Microanalysis, Interscience Publishers, (1963), 244.

(8) The Electron Microprobe, Edited by T.D.Mckinley et al., John Wiley \& Sons.Inc., (1966), 351.
光励起の影響はプラスにはきかず小さくなる傾向になる。 これは, 得られた結果とは必ずしも一致していない, 解析 結果の標準誤差からみても (Fig.5), $7 \mathrm{wt} \% \mathrm{Al}$ 以下では 2 元系と多元系で差がないとみることができる.

最後に Fe を含む Ti-Al-Fe-Cr 系の場合, $(\mu / \rho)$ FeK $\mathrm{Al}^{\mathrm{A}}$ と $(\mu / \rho) \underset{\mathrm{F} \text { eK } \alpha}{\mathrm{Cr}}$ は, $\mathrm{Fe}$ の自己質量吸収係数上り大きく, $\langle\mu / \rho)_{\mathrm{FeK} \alpha}^{\mathrm{A} 1}$ は $(\mu / \rho)_{\mathrm{FeK} \alpha}^{\mathrm{Ti}}$ より小さい. $\mathrm{Cr}$ が加わると多元系 の $(\mu / \rho){ }_{\mathrm{FeK} \alpha}^{\mathrm{Allog}}$ は大きくなる方向作用するが, 一方, $\mathrm{Al}, \mathrm{Fe}$ がさらに加わると $(\mu / \rho)$ FeK $\boldsymbol{\text { Alloy }}$ は小さくなる。 その程度は $2.5 \%$ 程度であり，その他の螢光励起効果はなく，原子番 号効果も考学る必要がないので，吸収効果の差だけで多元 系の方がX線強度が強くなるはずである。しかし得られた 結果は逆で，理論的な吸収効果だけでは説明ができない。

以上の上 5 に, 実験的に得られた結果の $X$ 線強度の大小 関係や検量線の 2 次項の係数の符号などを, 理論的には必 ずしもすっきりと説明することはできないが，すでに記し たように，質量吸収係数などの誤差，実験結果の統計解析 時の信頼限界を $95 \%$ にしたことからくる誤差を考慮する 必要があろう. Table 4 の質量吸収係数の值は, 例㕣ば他 の文献 ${ }^{(8)}$ の值と比較すると $20 \sim 25 \%$ 以上差のあるるのる あり，述べてきた傾向が変わる場合もあり得る。いずれに しても，理論的な補正が条件のよいときです8９\% とさ れている(3)ので，検量線法をあえて用いた意味もとこにあ ると考劣，少なくとも，ここに用いた合金系の範囲内で は，今後の定量試験に得られた検量線を使いらると考えら れた。

\section{V. 結 論}

$\mathrm{Al}, \mathrm{Fe}, \mathrm{Cr}, \mathrm{V}$ 扣よび Mo を含むチタン合金の微小領域 の合金元素濃度を EPMA により定量できるかどうかを知 るため, 検量線をまず求め, その検量線による定量試験お よび検量線法の適否を検討し, 次の結論を得た.

(1) $\mathrm{Al}, \mathrm{Fe}, \mathrm{Cr}, \mathrm{V}$ 㧊よび Mo の検量線は, 用いた試料 の範囲内では，2 次式あるいは1 次式であらわすことがで き, 回帰分析をして寄与率を求めると $99 \%$ 以上で, 1 20 wt\% の含有量に対し，最も精度の悪い $\mathrm{Al}$ でも $0.38 \mathrm{wt} \%$ 以下の誤差で検量線の得られることがわかった。

(2) Ti-1 Fe 执よび Ti-3 Fe を用いて定量試験を行な い, Ti-Fe 2 元系平衡状態図から得られる $\alpha$ 相, $\beta$ 相濃度 と比較したが, かなりよい一致を示し， $3 \mu$ 平方程度の面 積があれば十分精度よく定量できることがわかった。

(3) 2 元系チタン合金はもちろん，多元系チタン合金の 微小領域の濃度定量に, 検量線法が十分適用できると考兄 られた。 